\title{
Building A Data Quality Program With Dama International Framework In University
}

\author{
Hanung Nindito Prasetyo ${ }^{1}$ \\ \{hanungnp@gmail.com ${ }^{1}$ \} \\ Department of Information System Diploma, School of Applied Science, Telkom University ${ }^{1}$
}

\begin{abstract}
Development of information systems at the University, for example, an asset which cost quite expensive. Though the need of information systems within the University be an absolute asset to improve service to the academic community and information management performance of the University. As part of the global community, the University is required to place themselves in quality is able to answer the changes that occur in the environment. It also gives a great impact and influence on the company. The era of information technology has a tremendous impact for the company to provide a variety of services both internally and externally through the data and information generated. Data and information generated will certainly affect the decision-making process that occurs in various activities in the company. In this case Telkom University consisting of several faculties must have some functional unit organization implementing an information system that would produce data and information that is different. The thing that will happen is Telkom University will have a variety of data and information were great. In the fast-paced era of course, led the University requires accurate data and information. If the university with various levels of the organization do not have good data quality will certainly complicate the leadership of the University of Telkom in obtaining the information needed dala decision. Therefore we need the concept of the development of quality data in accordance with the needs of Telkom University.
\end{abstract}

Keywords: Data Quality, University, DAMA International

\section{Introduction}

Nowadays the world seems to be narrow, the information in countries in the western part of the world can be received up to date by countries in the east. The progress of information 
technology continues to displace towards globalization. It feels like the world is flat. As Thomas L Friedman said in his very famous book The World is Flat [1]:

When the world goes flat - and you are feeling flattened-reach for shovel and dig inside yourself. Don't try to build walls.

A message that is very wise in addressing the growing flow of information and technology by seeing it as an opportunity and challenge in expanding information networks and improving self-capability. There is no denying that every field of life and human activities require information. Sanders et al (2012) even suggested that there are three basic elements of human activities, namely: information, energy, and material [2]. As felt now that Information is also the substance of all human intellectual activities.

As part of a global community, universities are required to be able to put themselves in a quality capable of answering the changes that occur in their environment. The data and information produced will certainly greatly influence the decision-making process that occurs in various activities at the university. However, all universities are faced with data and information that are not adequate or are not fully trustworthy or the amount of data that is so great that it is often difficult to get reliable analysis results. In this context, good data management is needed. To manage data and good information requires good data quality [3]. In this case, Telkom University which consists of several faculties certainly has several functional units of organizations that implement information systems which of course produce different data and information. The thing that will happen is Telkom University will have a large variety of data and information. In a fast-paced era, of course, University leaders need accurate data and information. If the university with various levels of organization does not have good quality data, of course, it will make it difficult for Telkom University leaders to obtain information needed in decision making. Broadly speaking, this study will produce a design model for data quality case studies at Telkom University.

\section{$2 \quad$ Literature Review}

\subsection{Eksplorasi Manajemen Kualitas data dalam Tata Kelola Data}

Data governance is different from Information technology (IT) governance. IT governance makes decisions about IT investments, IT application portfolios, and IT project portfolios [4]. Data governance aligns IT strategies and objectives with enterprise strategies and objectives. CobiT ( Control Objective For Information and Related Technology ) provides IT governance standards, but only a small part of the CobiT framework discusses information management in DS11 [5]. Data governance is specifically intended for the management of data assets. Data governance is at the heart of managing data assets. This is in line with Microsoft Corporation 's data governance concept approach which explains that data governance does not replace IT governance, but as a complement [ 6 ]. IT governance focuses on defining IT investment portfolios, managing performance, and evaluating and managing risks for IT infrastructure [7]. 
There are several meanings of data governance. The following are some data governance definitions:

a. Data governance is decision making and authority for matters relating to data [17].

b. Data governance is a system of decision and accountability rights to process-related information, carried out in accordance with the model and which describes who can take what action, with what information, when, in what circumstances, using what method [8].

c. Data governance is defined as the processes, policies, standards, organizations, and technologies needed to manage and ensure availability, accessibility, quality, consistency, audit and data security in companies or institutions [7] [9].

The concept of data quality that will be used is adopted from the DAMA International data governance model.

International DAMA classifies data governance functions into 10 (ten) areas as shown below.

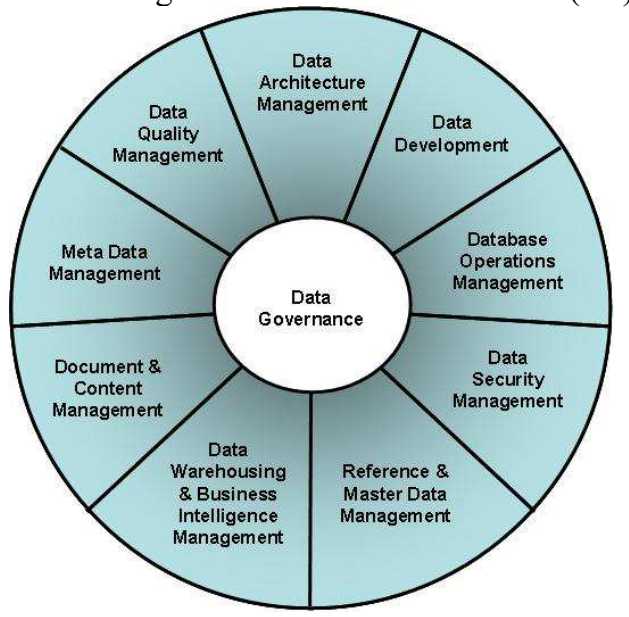

Figure. 1. Data Governance Model[10]

\subsection{Data Quality based on DAMA International Framework}

Based on the data governance model, the model that will be used as a reference is the DAMA data quality model. However, this model will be tested to produce a new model in accordance with the research objectives in universities, in this case, the Telkom University. The focus of data quality includes: 


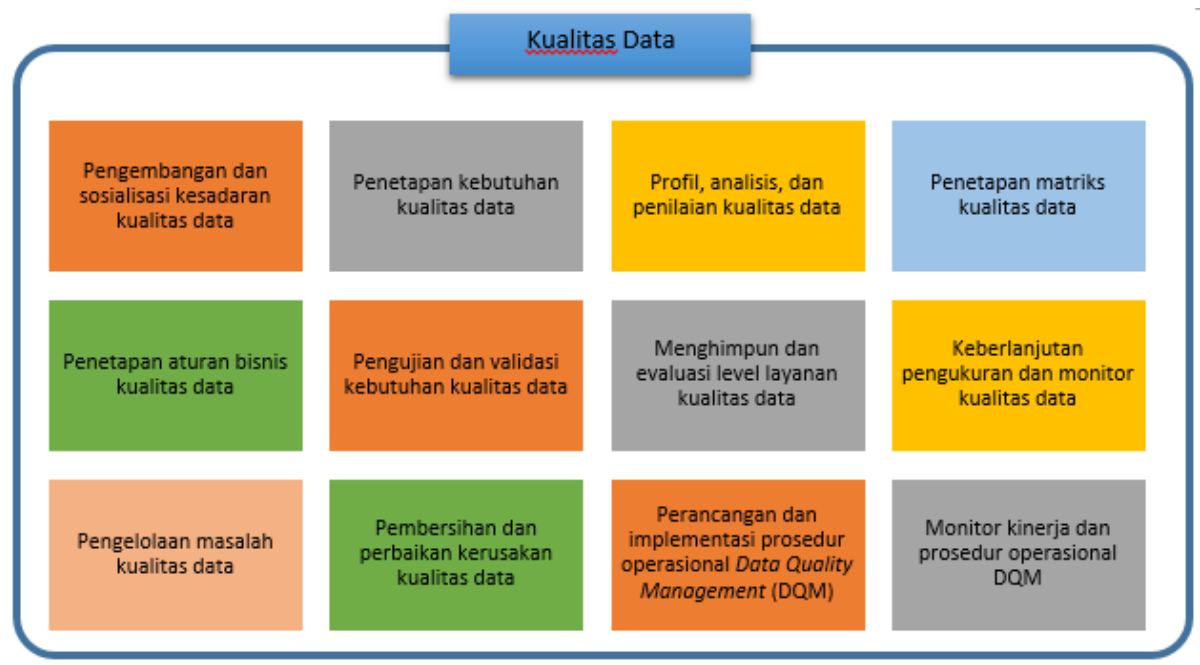

Figure 2. Data Quality Functions of the DAMA Framework [10]

\subsection{Others Research}

Quite a lot of research on data quality has been done abroad specifically related to organizational optimization such as how to measure the quality of air data in the City, the quality of health data based on the results of medical records. But related to research on the quality of data and information at Indonesian universities has not been found. Universities in Indonesia are unique organizations that have the concept of Tri Dharma Perguruan Tinggi, namely education and teaching, research and community service. Related to this, of course, universities have an interest in the data and information produced. The data and information produced are certainly able to support the achievement of the university to become World Class University(WCU). During the initial research period, references were collected in the form of papers related to the research being conducted. The following is a list of journals and a description of the contents of the journal related to the research.

Table 1. Previous Research Study

\begin{tabular}{|c|c|c|c|}
\hline No & Judul Paper \& Jurnal & Penulis & Deskrpsi terkait penelitian \\
\hline 1 & $\begin{array}{l}\text { Can We Trust Our } \\
\text { Results? A Mapping } \\
\text { Study on Data Quality } \\
\text {, } 2013 \text { 20th Asia-Pacific } \\
\text { Software Engineering } \\
\text { Conference } \\
\text { (APSEC)_(Volume:1 ) }\end{array}$ & Marshima Mohd Rosli & $\begin{array}{l}\text { This paper describes the explanation that good } \\
\text { software requires analysis in advance regarding } \\
\text { the quality of data to be managed in the system } \\
{[11] \text {. }}\end{array}$ \\
\hline 2 & $\begin{array}{l}\text { Data migration } \\
\text { challenges: The impact } \\
\text { of data quality - Case } \\
\text { study of University } \\
\text { Putra Malaysia UPM, }\end{array}$ & $\begin{array}{l}\text { Ikhlas Fuad Zamzami, } \\
\text { Hanan Abdullah A. } \\
\text { Fatani ; Nuha Abdullah } \\
\text { H. Zammarah }\end{array}$ & $\begin{array}{l}\text { This paper explains the concept of data migration } \\
\text { in a college database. Data migration is an } \\
\text { important process that directly affects the quality } \\
\text { of data management. Data migration has affected } \\
\text { data quality, such as accuracy, data elements, and }\end{array}$ \\
\hline
\end{tabular}


2011 International

Conference on Research and Innovation in

Information Systems

3 Beyond Accuracy: What Data Quality Means to Data Consumers, Journal of Management Information Systems, Vol. 12, No. 4 (Spring, 1996), Journal of Management

Information Systems, Vol. 12, No. 4 (Spring, 1996), pp. 5-33

4 Towards Implementing Total Data Quality Management In A Data Warehouse, Journal of Information Technology Management ISSN \#1042-1319

5 Data Quality Management using

Business Process Modeling ,2006 IEEE International Conference on Services Computing (SCC'06) data accessibility, and all data shows. However, many organizations face all the different challenges with data under the same process. This paper discusses the challenges of data migration that have been encountered in the University and that affect data quality [12].

Richard Y. Wang and This paper explains that many databases are not Diane M. Strong error-free, and some contain unusually large errors. It was noted that more than 60 percent of the companies surveyed $(500$ mid-sized companies with annual sales of more than $\$ 20$ million) had problems with data quality. The purpose of this study is to develop a framework that captures important data quality aspects related to consumer data[13].

g. shankaranarayanan

This paper explains the low quality of data in the data warehouse that will negatively impact the usability of the data warehouse. In this article, a framework for managing data quality in the data warehouse is described. The most important thing about this paper is that it offers an intuitive approach to not only managing quality data in the data warehouse but also implementing total data quality management. The framework is based on the product information approach. This allows decision-makers to be able to measure data quality [14].

Sugato Bagchi, Xue This paper explains the quality of data contained Bai, Jayant Kalagnanam in a company's information system has a significant impact, both from the business decision making of the internal perspective and the obligations of the government and external shareholders.assessment of the quality of this data in business processes by proposing a modeling framework for measuring data quality in an information processing system. In addition, this paper also presents a business process modeling framework for analyzing data quality and developing mathematical formulations for error propagation. This framework allows the estimation and management of data quality when facing changes in various aspects of business processes [15]. 


\section{Research Methods}

In this study, the subject is analyzing, designing and developing a data quality model in Higher Education with case studies at Telkom University.

\subsection{Method of collecting data}

The data collection methods carried out in this study are as follows

1. Library Studies are carried out by searching journals, articles, e-books and literature that discusses Data Quality and information technology. Library studies will be conducted via the web browsing the internet and visiting the library that provides literature on the quality of data and information to obtain material related to research.

2. Interview method, which is asking questions or question and answer directly. This method is to ensure data obtained about information management at Telkom University.

3. Observation (Direct Research), which is a method of collecting data or facts that is quite effective by making observations and recording with a direct review of the units in each faculty in the Telkom University environment to obtain information needed as research material.

4. Comparative studies, conducting comparative studies and data and information management surveys in other universities that are considered to have good data quality.

\subsection{Research methodology}

The methodology of this research is to use the Design Science Research Methodology Method (DSRM) used to explore the analysis carried out on the object of research put forward by Pfeffer in 2007 which has 6 (six) steps to be carried out, namely, problem identification, goal setting, design and development, case studies, evaluation, and communication. This research will only be carried out until the design and development stage. The Design Science Research Methodology (DSRM) method is shown in the Figureure:

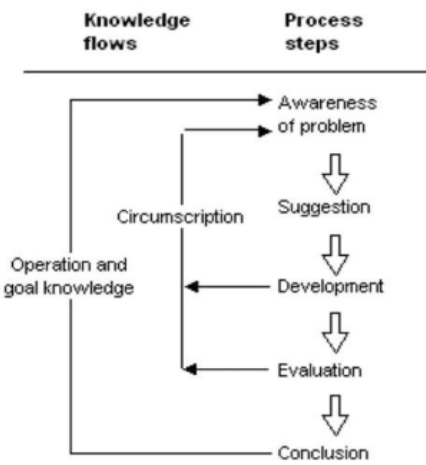

Figure 3 Design Science Research Methodology[16] 


\section{Building Data Quality in Telkom University}

\subsection{Pengembangan Dan Sosialisasi Kesadaran Kualitas Data}

In this case, the development and socialization of data quality awareness require support in the form of commitment from higher education management with the need to establish a data quality board that can consist of policyholders up to designated data managers through special policies. This is needed to guard the process of improving data quality in universities. There are no proposals that can be based on the interests and needs of data quality management. Here is a suggestion for some roles that can Dija $d$ fish as a board member at the University of Telkom's data quality.

Table 2. Role in the Data Quality Board

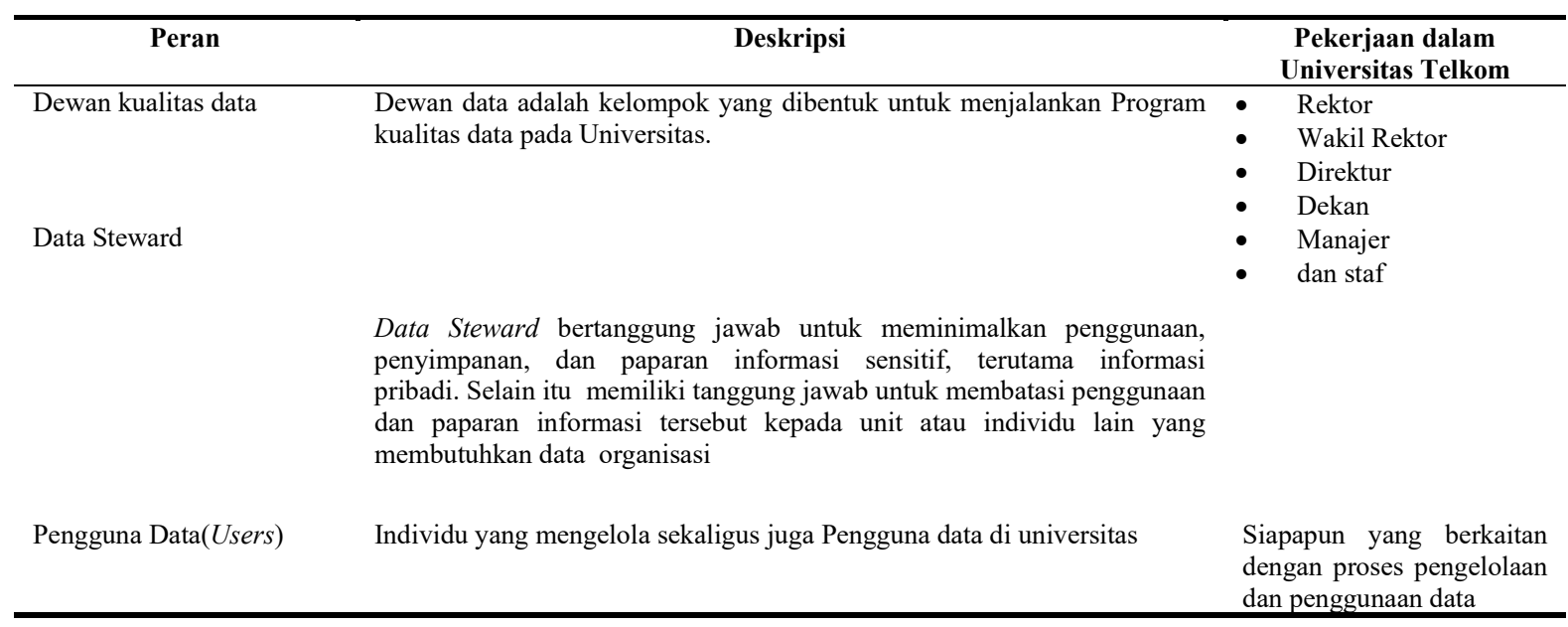

Source: results of research analysis

\subsection{Determination of data quality requirements}

Problems among universities, of course, different in data and information management issues. Until now, there are still many universities that are not aware that the data generated during their processes and activities are extraordinary data assets because they are considered as intangible assets, namely non-monetary assets identified without physical form. As a result, resolving various problems in terms of data management is also partial. Besides that in terms of organizational development, higher education institutions should be supported by optimal performance.

Optimal performance will be realized if supported by valid data and information. Data and information generated during the running processes will greatly influence the decisionmaking process that occurs in a variety of activities at the college. What determines the data quality needs is the leadership of Telkom University. The data obtained must be able to determine the direction and objectives to be achieved by Telkom University.. 


\subsection{Profile, analysis, and assessment of data quality}

In terms of determining the profile, it is based on the level of maturity of the data quality that is in college to see the strength of the quality of the data owned by h Telkom University. Measurements of assessment using data quality maturity questionnaire with the CMMI approach. Based on the survey obtained an assessment of the level of maturity of the data quality as shown in the following Figureure:

Table 3. Assessment of Data Quality Maturity Levels

\begin{tabular}{clc}
\hline No & \multicolumn{1}{c}{ Fungsi Kualitas Data } & $\begin{array}{c}\text { Nilai } \\
\text { Tingkat } \\
\text { Kematangan }\end{array}$ \\
\hline 1 & Development and awareness of data quality awareness & 2.87 \\
2 & Determination of data quality requirements & 3.57 \\
3 & Profile, analysis, and assessment of data quality & 2.57 \\
4 & Determination of data quality matrix & 3.15 \\
5 & Determination of data quality business rules & 3.08 \\
6 & Testing and validating data quality requirements a & 2.33 \\
7 & Testing and validating data quality requirements & 3.15 \\
8 & Collect and evaluate data quality service levels & 2.25 \\
9 & Continuity of measurement and monitoring of data & \\
& quality & 2.82 \\
10 & Management of data quality problems & 3.27 \\
11 & Cleaning and repairing data quality damage & 1.82 \\
12 & Design and implementation of operational procedures & \\
& for Data Quality Management & 2.1 \\
Average & 2.74 \\
\hline Sourata
\end{tabular}

Source: results of research analysis

Based on the table it can be shown a profile that in the maturity of Telkom University data quality has the potential for superiority in functions

1. determination of data quality requirements

2. determination of data quality matrix

3. testing and validating data quality requirements

4. management of data quality problems

Survey results of the general university get a value of 2.74 , which means the organization is still at level 2 or level Managed. Managed level means the stage where the Telkom University organization has a pattern for managing related processes based on the success of repeated experiences that have been done before, but the pattern that is carried out does not yet have standards that can meet data quality. When referring to the normative value used is 3 (three), then the University of Telemoms can meet national standards. The national standard used refers to the SOE Ministry Regulation PER-02 / MBU / 2013 regarding guidelines for the preparation of IT BUMN management which targets that the minimum level at level 3 (three). 
Maturity level gap analysis can be used as a reference and recommendation for monitoring data quality programs regularly at Telkom University.

\subsection{Penetapan Matriks Kualitas Data}

One of model that can be used is the RACI model to describe the role of running operational data quality management. This can be shown, as needed at Telkom University in the following table::

Table 5. RACI Matrix Data quality

\begin{tabular}{|c|c|c|c|c|c|}
\hline No & Function & Role & $\begin{array}{c}\text { Data } \\
\text { Quality } \\
\text { Commitee }\end{array}$ & $\begin{array}{c}\text { Head of } \\
\text { Data } \\
\text { steward }\end{array}$ & $\begin{array}{c}\text { Data } \\
\text { Steward } \\
\text { Function }\end{array}$ \\
\hline 1 & Development and awareness of data quality awareness & & $\mathrm{R}$ & $\mathrm{R}$ & $\mathrm{R}$ \\
\hline 3 & Profile, analysis, and assessment of data quality & & $\mathrm{R}$ & I & $\mathrm{C}$ \\
\hline 4 & Determination of data quality matrix & & I & $\mathrm{R}$ & $\mathrm{C}$ \\
\hline 5 & Determination of data quality business rules & & $\mathrm{R}$ & A & I \\
\hline 8 & Collect and evaluate data quality service levels & & $\mathrm{C}$ & $\mathrm{R}$ & A \\
\hline 9 & Continuity of measurement and monitoring of data quality & & $\mathrm{R}$ & $\mathrm{C}$ & A \\
\hline 10 & Management of data quality problems & & $\mathrm{C}$ & $\mathrm{R}$ & A \\
\hline \multirow[t]{2}{*}{11} & Cleaning and repairing data quality damage & & $\mathrm{C}$ & I & A \\
\hline & Design and implementation of operational procedures for Data Quality & & I & $\mathrm{R}$ & A \\
\hline
\end{tabular}

Description: $\mathrm{R}=$ Responsible $\mathrm{A}=$ Accountable, $\mathrm{C}=$ Consult, $\mathrm{I}=$ Inform

\subsection{Establishing Data Quality Business Rules}

Determination of business rules data quality in this case, can be done with the approach of mapping business processes at universities Particularly Telkom University to see transaction data goes in college. The process in higher education refers to the concept of higher education, in this context one of the main processes will be described, namely education and teaching.

The process of education and teaching is a business process skills development of students. The development of student skills is the development of competencies (vocational) owned by students so that they meet the competency profile standards set by the study program. Students who have met the study profile competency standard are referred to as graduates. Graduates are the output of competency development business processes, while the required inputs are prospective students. Graduates who have worked are then known as alumni ( outcome ). To achieve graduate profile requirements needed by the industry, valid data is needed in every running process. The data obtained is used as a reference in monitoring and evaluating the process of forming student skills.. 


\subsection{Testing and Validating Data Quality Needs}

For the determination of data quality requirements, a data quality model is needed that is in accordance with the characteristics of the needs in the Higher Education Therefore, it is necessary to identify the function of data quality in higher education. The method is by testing the data quality model in accordance with the data quality requirements with a multiple regression approach to see which variables in data quality are the main needs and support needs. In this case, the testing instrument is in the form of a questionnaire.

To determine the measurement, the initial quality model of the data used in college is determined. The model for assessment can be seen in the following table:

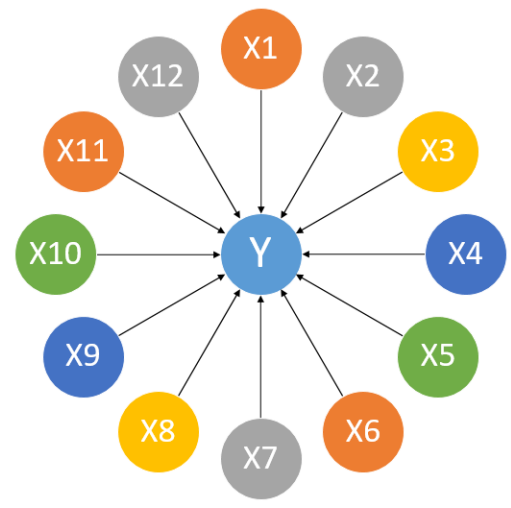

Figure. 4. Research model variable

The variables described are as follows:

\begin{tabular}{|c|c|c|c|c|}
\hline $\mathbf{X 1}$ & $\begin{array}{l}\text { Development and awareness of data } \\
\text { quality awareness }\end{array}$ & $\mathbf{X} 7$ & $=$ & validating data quality \\
\hline $\mathbf{X} 2$ & $\begin{array}{l}\text { Determination of data quality } \\
\text { requirements }\end{array}$ & $\mathbf{X 8}$ & $=$ & $\begin{array}{l}\text { Collect and evaluate data quality service } \\
\text { levels }\end{array}$ \\
\hline $\mathbf{X 3}$ & $\begin{array}{l}\text { Profile, analysis, and assessment of } \\
\text { data quality }\end{array}$ & X9 & $=$ & $\begin{array}{l}\text { Continuity of measurement and monitoring of } \\
\text { data quality }\end{array}$ \\
\hline$=$ & Determination of data quality matrix & $\mathbf{X 1 0}$ & $=$ & Management of data quality problems \\
\hline$=$ & $\begin{array}{l}\text { Determination of data quality business } \\
\text { rules }\end{array}$ & X11 & $=$ & Cleaning and repairing data quality damage \\
\hline$=$ & $\begin{array}{l}\text { Testing and validating data quality } \\
\text { requirements }\end{array}$ & $\begin{array}{l}\text { X12 } \\
\text { Y }\end{array}$ & $=$ & $\begin{array}{l}\text { Design and implementation of operational } \\
\text { procedures for Data Quality Management } \\
\text { Data Quality }\end{array}$ \\
\hline
\end{tabular}

It was conducted a survey of 20 respondents, then the data was processed and fulfilled the assumptions:

1. Data has Normal distribution

2. Heteroscedasticity

3. Multicollinearity

Then the data is processed and the results of multiple regression are obtained as follows:: 
Tabel 6. Data processing of data quality model

\begin{tabular}{|c|c|c|c|c|c|c|c|c|}
\hline & Coefficients & Standard Error & t Stat & P-value & Lower $95 \%$ & Upper $95 \%$ & Lower $95.0 \%$ & Upper $95.0 \%$ \\
\hline Intercept & 12.89559962 & 8.497157508 & 1.517637 & 0.172895 & -7.19698509 & 32.98818434 & -7.19698509 & 32.98818434 \\
\hline $\mathrm{X} 1$ & 0.795237993 & 0.333767974 & 2.382607 & 0.048695 & 0.006002148 & 1.584473838 & 0.006002148 & 1.584473838 \\
\hline $\mathrm{X} 2$ & -0.631264329 & 0.423821197 & -1.48946 & 0.179979 & -1.633442211 & 0.370913553 & -1.633442211 & 0.370913553 \\
\hline $\mathrm{X} 3$ & -0.324672904 & 0.330233867 & -0.98316 & 0.358281 & -1.105551914 & 0.456206106 & -1.105551914 & 0.456206106 \\
\hline $\mathrm{x} 4$ & -0.434659479 & 0.343438981 & -1.26561 & 0.246148 & -1.246763623 & 0.377444665 & -1.246763623 & 0.377444665 \\
\hline X5 & 0.154743591 & 0.617103898 & 0.250758 & 0.809203 & -1.304475252 & 1.613962435 & -1.304475252 & 1.613962435 \\
\hline X6 & -0.115233547 & 0.580084734 & -0.19865 & 0.848183 & -1.486915976 & 1.256448883 & -1.486915976 & 1.256448883 \\
\hline$x 7$ & 0.544379988 & 0.477792117 & 1.139366 & 0.292034 & -0.58541884 & 1.674178816 & -0.58541884 & 1.674178816 \\
\hline X8 & -1.555780963 & 0.887154529 & -1.75368 & 0.122932 & -3.653568076 & 0.54200615 & -3.653568076 & 0.54200615 \\
\hline X9 & 0.842345325 & 1.055095813 & 0.798359 & 0.450894 & -1.652559821 & 3.337250472 & -1.652559821 & 3.337250472 \\
\hline $\mathrm{X} 10$ & 1.777546547 & 0.500392025 & 3.552308 & 0.009315 & 0.594307428 & 2.960785665 & 0.594307428 & 2.960785665 \\
\hline X11 & -0.007955112 & 0.45222926 & -0.01759 & 0.986456 & -1.077307387 & 1.061397164 & -1.077307387 & 1.061397164 \\
\hline $\mathrm{X} 12$ & -0.178211381 & 0.575091028 & -0.30988 & 0.765671 & -1.538085572 & 1.181662811 & -1.538085572 & 1.181662811 \\
\hline
\end{tabular}

Source: results of research analysis

Based on the table above it can be shown that of the twelve independent variables included in the model, it turns out that there are 2 (two) variables namely X1 and X10 significant at $\alpha=5 \%$. This can be seen from the value of the $p$-value of the two variables smaller than 0.05 . thus can be concluded that the main variables that become the focus in data quality program at the University of Telkom is X1 namely the development and dissemination of data quality awareness and X10 are m a wrongmanagement of data quality. Then the model that will be used as a reference is as shown in the following Figureure:

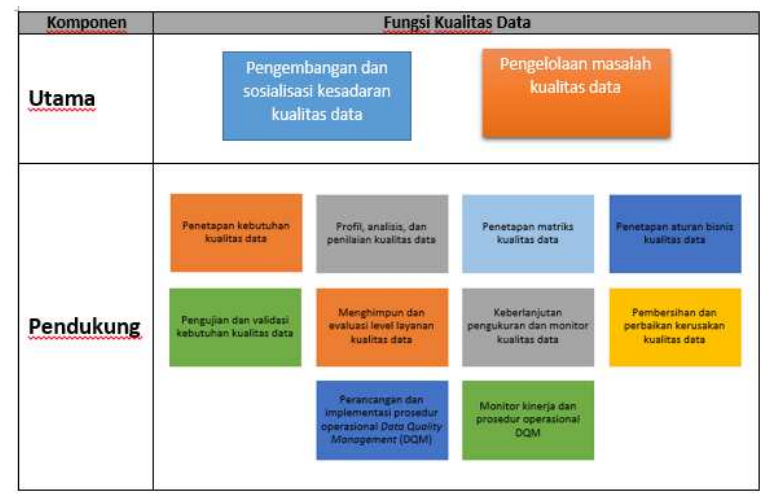

Figure. 5. Data Quality Model of Telkom University 


\subsection{Collecting and Evaluating Data Quality Service Levels}

The description of the data quality service process built is based on the model that has been established through measurement as a result, namely Telkom universities focus on the main and supporting services as shown.

\subsection{Sustainability of Data Quality Measurement and Monitor}

In terms of the continuity of measurement and monitoring of basic quality, the person in charge of the program conducts periodic and periodic measurements, to see the progress of the program where each measurement result is adjusted to the data quality program roadmap that has been determined and agreed upon. Normative measurements can program generally done periodically every 12 months or 1 year the program runs.

\subsection{Management of Data Quality Problems}

The description also shows who has the role of a responsible person and data manager. It is necessary to determine the role that is responsible for the implementation of data quality programs, both individuals and groups, for the purpose of building quality and accountability for clear organizational data. This policy does not affect daily activities, but rather must be embedded and become part of the roles and responsibilities of employees such as:

a. Deputy Chancellor for Academic Affairs. The Vice-Chancellor for Academic Affairs is the main organizational officer responsible for developing and implementing a Data Quality program at Telkom University. System policies and problems are the authority and responsibility of being in the Vice Chancellor for Academic Affairs.

b. Deputy Chancellor in charge of Information Technology and Head/director of Information technology. The Deputy Chancellor in charge of Information Technology and the Head / Information technology director is responsible for establishing and enforcing standards and guidelines for management technology data and systems related to computing infrastructure, data processing performance, data crossing and integration, architecture and data structures, metadata repositories and access control mechanisms.

c. The Chancellor and included in this matter is the senate (collectively referred to as leadership at the University of Telkom ) having authority and responsibility for policies and procedures regarding access and use of data in delegating authority.

d. Data Quality Committee

This committee is a group formed to implement a data quality program at Telkom University. Committee members are appointed by the Vice-Chancellor for Academic Affairs. The committee's main task is to:

- revise, recommend, and develop policies and standards.

- regulating University data and information management practices under the direction of Telkom University leadership.

- clearly and consistently define structures, models, and processes that support efficient use of resources to meet the information needs of the academic community.

- provide guidance and recommendations regarding University organization data, including expanding access, improving quality, ensuring security, and improving performance; 
- provide recommendations to Telkom University leadership if there are disputes surrounding organizational data and Organizational Data Systems.

e. Data Manager (Data Stewards). Data stewards act accordingly and ensure compliance with the Ministry of Education and Culture's DIKTI Directorate General regulations and University regulations and policies involving Organizational Data. Data Stewards are responsible for minimizing the use, storage and exposure of sensitive information, especially personal information.

f. User Data ( Data Users ) are individuals who, to fulfill work duties and responsibilities, need access to sensitive information as defined in established executive policies, security, and protection of sensitive information, and therefore are given access. Data users are responsible for understanding and complying with all applicable University policies and procedures for handling information including data protection.

\subsection{Cleaning and Repairing Data Quality Damage}

In principle, it can be seen that data and information obtained from invalid processes and tools will result in invalid decisions. In this case, a mechanism for cleaning up and improving the quality of data is needed periodically and consistently through established procedures. Cleaning and improving the quality of data is carried out periodically and carried out on the basis of recommendations.

\subsection{Design and Implementation of Data Quality Management Operational Procedures}

The design and implementation of operational data quality management procedures is based on the policies and rules set by the committee. The procedure created is based on the needs and focus on functions obtained based on measurement and assessment of the quality of data that has been obtained periodically.

\subsection{Monitoring Performance of Data Quality Management Operational Procedures}

Telkom University monitors the performance of data quality management operational procedures specified in the rules and policies that have been determined. Operational procedures for data quality management are measured periodically to ensure the success of obtaining quality data for the institution.

\section{Conclusion}

Based on the discussion above, conclusions are obtained, namely:

1. The model and level of quality of data obtained are the focus of development at Telkom universities.

2. The results of the model and the level of maturity of the quality of the data obtained can be recommendations and references in the construction of data quality programs at Telkom University. 


\section{References}

[1] T. Friedman, "The World is Flat Chapt 13," p. 488, 2005.

[2] and J. G. S. Nicholson, J. W., S. T. Weidman, ""Sanders' energy-release rate integral for a circumferentially cracked cylindrical shell." Journal of applied mechanics 50.2,” pp. 373-378, 1983.

[3] L. Al-Hakim, "Information quality management: theory and applications. IGI Global, 2007."

[4] A. Katz, "A Manager's Guide to IT Law.British Informatics Society Limited (BISL), Swindon UK," 2004.

[5] B. Y. dan A. Arinanda, "Metode Perancangan Struktur Fungsi Dan Peran Tata Kelola Data Berbasis Cobit.. Journal of Information System, Volume 6, Issues 2, October," 2010.

[6] S. Cameron, “A. Enterprise content management. British Informatics Society Limited,” 2011.

[7] B. Sandrino-Arndt, "C. P. (2008) : People, Portfolios and Processes:The 3 P Model of IT Governance. Information System Control Journal. International Federation of Accountants;"

[8] Grembergen, "W. V., De Haes, S., Guldentops, E, (2004) : Strategies for Information Technology Governance. USA : Idea Group Publishing,."

[9] IT, "Governance Institute. (2003) : Board Briefing on IT Governance, 2nd Edition, diakses Desember 2012 dari http://www.itgi.org."

[10] Mosley, "M., Brackett M., Earley S., Henderson D. (2009) : The DAMA Guide to The Data Management Body of Knowledge (DAMA-DMBOK Guide). USA : Technics Publications, LLC."

[11] Rosli, "Marshima Mohd, Ewan Tempero, and Andrew Luxton-Reilly. 'Can we trust our results? a mapping study on data quality.' 2013 20th Asia-Pacific Software Engineering Conference (APSEC). Vol. 1. IEEE, 2013."

[12] Zamzami, "Ikhlas Fuad, Hanan Abdullah A. Fatani, and Nuha Abdullah H. Zammarah. 'Data migration challenges: The impact of data quality — Case study of University Putra Malaysia UPM.' 2011 International Conference on Research and Innovation in Information Systems. IEE."

[13] Wang, "Richard Y., and Diane M. Strong. 'Beyond accuracy: What data quality means to data consumers.' Journal of management information systems 12.4 (1996): 5-33.”

[14] Shankaranarayanan, "G. 'Towards implementing total data quality management in a data warehouse.' Journal of Information Technology Management 16.1 (2005): 21-30.”

[15] Bagchi, “, Sugato, Xue Bai, and Jayant Kalagnanam. 'Data quality management using business process modeling.' 2006 IEEE International Conference on Services Computing (SCC'06). IEEE, 2006."

[16] Peffers, "Ken, Tuunanen Tuure,Rothenberger Marcus A., Chatterjee.(2007): A Design Science Research Methodology for Information Systems Research. Journal of Management Information Systems. Volume 24 Issue 3, Winter 2007-8 pp. 45-78."

[17] Sunil, "Soares (2011): The IBM Data Governance Unified Process; Driving Business Value with IBM Software and Best Practices. USA Ketchum : MC PRES." 